\title{
PASAR MONOPOLI
}

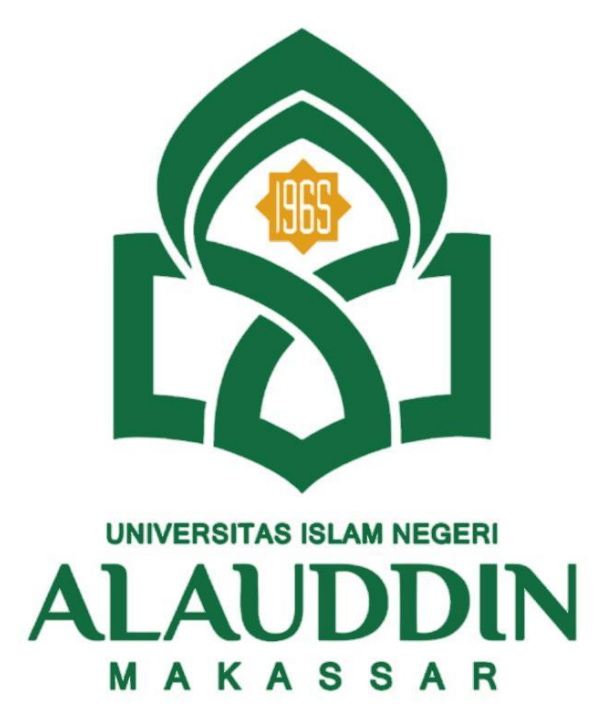

Disusun Oleh :

Ananda Magfirah (90500120077)

Nur Aprilia (90500120076)

Ayuni Nurrahma (90500120079)

JURUSAN PERBANKAN SYARIAH

FAKULTAS EKONOMI DAN BISNIS ISLAM

UNIVERSITAS ISLAM NEGERI ALAUDDIN MAKASSAR 


\section{KATA PENGANTAR}

Puji syukur kehadirat Allah SWT yang telah memberikan rahmat dan hidayah-Nya sehingga saya dapat menyelesaikan tugas makalah yang berjudul PASAR MONOPOLI ini tepat pada waktunya.

Adapun tujuan dari penulisan dari makalah ini adalah untuk memenuhi tugas akhir pada mata kuliah Ekonomi Mikro Syariah . Selain itu, makalah ini juga bertujuan untuk menambah wawasan tentang PASAR MONOPOLI bagi para pembaca dan juga bagi penulis.

Saya menyadari, makalah yang saya tulis ini masih jauh dari kata sempurna. Oleh karena itu, kritik dan saran yang membangun akan saya nantikan demi kesempurnaan makalah ini.

Gowa, 16 November 2021

Penulis 


\section{DAFTAR ISI}

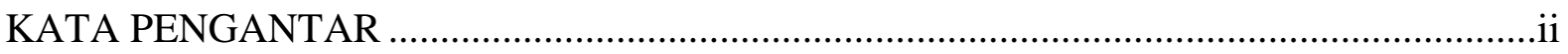

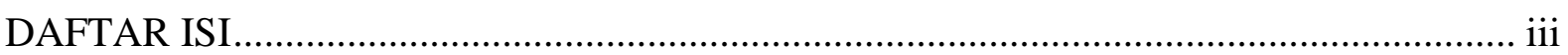

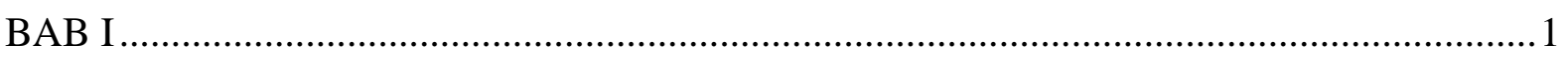

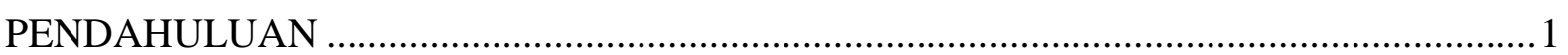

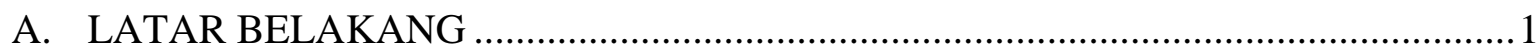

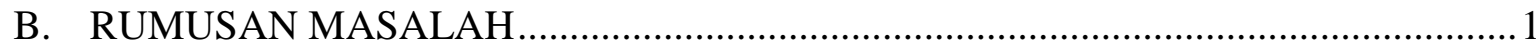

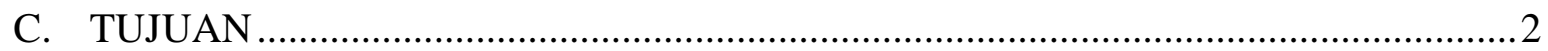

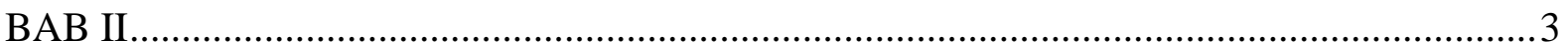

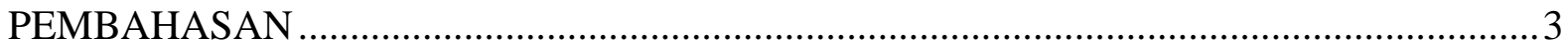

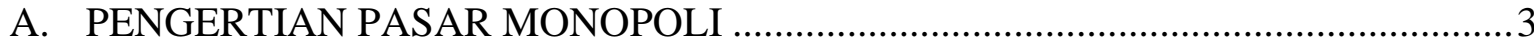

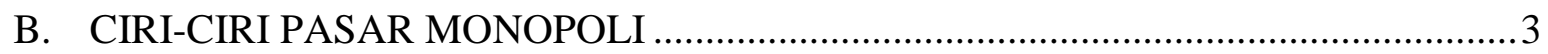

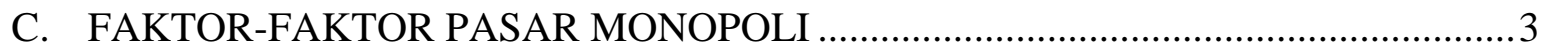

D. KURVA PERMINTAAN DAN KEKUATAN MONOPOLI ......................................

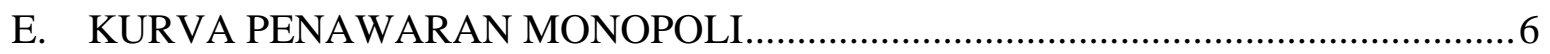

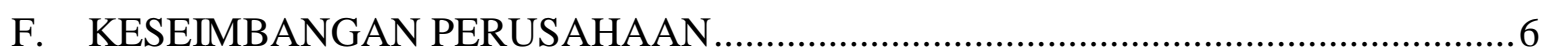

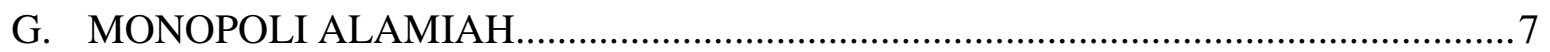

H. KEBAIKAN DAN KEBURUKAN MONOPOLI .................................................

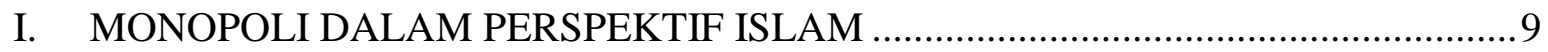

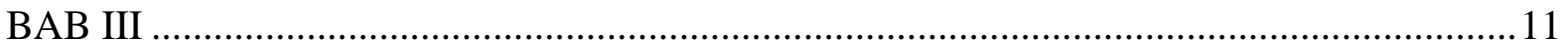

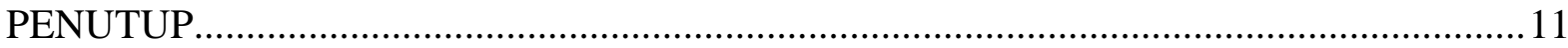

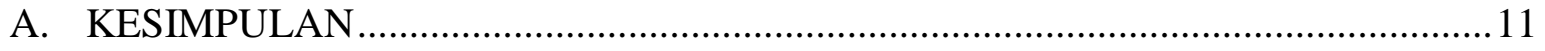

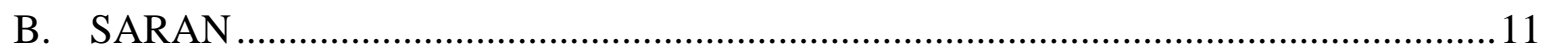

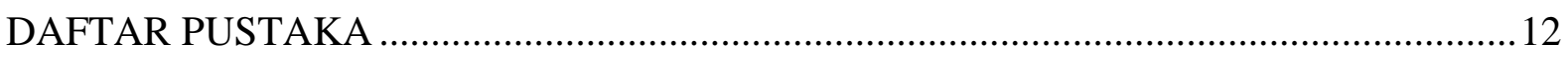




\section{BAB I \\ PENDAHULUAN}

\section{A. LATAR BELAKANG}

Pasar adalah salah satu dari berbagai sistem, industri, prosedur, hubungan sosial dan infrastruktur di mana usaha menjual barang, jasa dan tenaga kerja untuk orang-orang dengan imbala uang. Kegiatan ini merupakan bagian dari perekonomian. Persaingan sangat penting dalam pasar, dan memisahkan pasar dari perdagangan.

Pasar sebagai kumpulan jumlah pembeli dan penjual individual mempunyai karakteristikkarakteristik tertentu. Karakteristik tersebut muncul karena masing-masing pembeli dan penjual individual mempunyai perilaku individual yang berbeda pula. Pasar dengan karakteristik tersebut disebut dengan pasar monopoli. Mengingat dalam pasar monopoli hanya terdapat satu penjual dari satu produk (barang atau jasa) yang tidak mempunyai alternatif produk pengganti (subtitusi) maka dalam pasar monopoli tidak ada persaingan dari penjual lain.

Dalam kehidupan perekonomian yang factual, sangat jarang mendapat penjual yang tidak menghadapi persaingan dari penjual lain. Meskipun dalam suatu pasar misalnya hanya terdapat satu penjual sehingga tidak ada persaingan secara langsung dari penjual lain, tetapi penjual tunggal tersebut akan menghadapi persaingan secara tidak langsung dari penjual lain yang menghasilkan produk yang dapat merupakan alternative produk pengganti yang tidak sempurna.

\section{B. RUMUSAN MASALAH}

1. Apa yang dimaksud dengan definisi pasar monopoli

2. Mengidentifikasi faktor-faktor pasar monopoli

3. Mengidentifikasi ciri-ciri pasar monopoli

4. Mengidentifikasi kurva penawaran dan permintaan pasar monopoli

5. Mengidentifikasi kekurangan dan kelebihan pasar monopoli

6. Pasar monopoli dalam perspektif islam 


\section{TUJUAN}

1. Dapat memahami tentang pasar monopoli.

2. Mengetahui ciri-ciri pasar monopoli.

3. Mengetahui macam-macam pasar monopoli.

4. Mengetahui jenis-jenis pasar monopoli.

5. Mengetahui faktor yang menimbulkan monopoli.

6. Mengetahui kelebihan dan kelemahan dari pasar monopoli.

7. Mengetahui contoh pasar monopoli.

8. Mengetahui jenis-jenis monopoli yang tidak dilarang.

9. Mengetahui tentang undang-undang monopoli.

10. Mengetahui kebijakan pemerintah anti monopoli. 


\section{BAB II \\ PEMBAHASAN}

\section{A. PENGERTIAN PASAR MONOPOLI}

Definisi Pasar Monopoli

Definisi pasar monopoli adalah gambaran sebuah pasar yang terbentuk karena munculnya seluruh penawaran terhadap produk baik barang maupun jasa kepada seorang penjual atau beberapa penjual tertentu.

Jadi inti dari jenis pasar ini adalah dalam pasar ini hanya ada satu kekuatan atau kekuasaan pihak yang menguasai pasar dan mendominasi terjadinya transaksi ekonomi. Apabila barang dan jasa yang dibutuhkan tidak ada yang menyerupai atau menggantikan barang atau jasa tersebut maka kondisi pasar yang dikuasai oleh satu penjual akan terus berlangsung.

\section{B. CIRI-CIRI PASAR MONOPOLI}

- Adapun ciri-ciri pasar monopoli adalah sebagai berikut:

- Hanya ada satu penjual.

- Terdapat banyak pembeli.

- Produk untuk pasar monopoli tidak mempunyai barang pengganti yang dekat.

- Terdapat hambatan untuk masuk ke dalam pasar.

\section{FAKTOR-FAKTOR PASAR MONOPOLI}

Faktor Terjadinya Pasar Monopoli,berikut ini merupakan beberapa faktor yang menjadi penyebab terjadinya pasar monopoli,Yaitu:

1. Perusahaan Mempunyai Sumber Daya Eksklusif

Jika suatu perusahaan atau organisasi bisnis mempunyai dan menguasai sumber daya yang tidak dimiliki dan dikuasai oleh organisasi bisnis lainnya, maka hal tersebut berarti organisasi bisnis yang menguasai sumber daya tersebut lah yang dapat menghasilkan produk.

Oleh karena itu, di pasar organisasi bisnis tersebutlah yang hanya bisa memproduksi dan menjual suatu produk tertentu.

Contohnya seperti, NASA dari Amerika Serikat yang membuat roket. Sebelum Cina dan konsorsium Inggris dan Prancis bisa membuat roket untuk membawa satelit ke orbit-nya, NASA pada saat ini me-monopoli untuk usaha ini. 
Dalam contoh tersebut dapat disimpulkan bahwa NASA mempunyai kemampuan efisiensi yang masih belum bisa ditiru, penguasaan bahan baku, dan penguasaan teknologi serta tenaga ahli.

2. Kebijakan Pemerintah / Hak Eksklusif

Pemerintah tentunya dapat memberikan hak kepada suatu organisasi atau perorangan untuk melakukan monopoli.

Tujuan pemerintah tersebut supaya organisasi bisnis atau perorangan tersebut untuk memproduksi suatu produk yang dianggap penting bagi pemasukan industri dalam negeri.Oleh karena hal tersebut pemerintah akan memberikan jaminan dalam bentuk peraturan dengan tenggang waktu yang relatif lama.Artinya selama masa pemberian hak monopoli tersebut, hanya organisasi bisnis atau perorangan yang ditunjuk saja lah yang bisa menghasilkan, menyediakan, dan menggandakan suatu produk.

Misalnya seperti PT Bogasari yang ditunjuk oleh pemerintah untuk melakukan monopoli tepung terigu (import).Bagi perusahaan tersebut kebijakan dalam menentukan harga berada di tangan pemerintah, sedangkan untuk kegiatan pemasaran-nya dilakukan oleh perusahaan.

3. Amanat Undang - Undang

Di Indonesia terdapat beberapa produk atau sumber daya yang hanya dikuasai atau di monopoli oleh negara.

Berdasarkan UUD 1945 Pasal 33 ayat 2, menyebutkan bahwa:

"Cabang - cabang produksi yang penting bagi negara dan yang menguasai hajat hidup orang banyak dikuasai oleh negara."

Berdasarkan UUD 1945 Pasar 33 ayat 3, menyebutkan bahwa:

"Bumi dan air dan kekayaan alam yang terkandung di dalam nya dikuasai oleh negara dan dipergunakan untuk sebesar - besar kemakmuran rakyat."

Ke 2 pasal tersebut berarti bahwa negara menguasai dalam bentuk atau dengan melalui perusahaan negara yang ditunjuk untuk mengelolanya, dengan ketentuan harga dan juga kebijakan pemasaran berada di tangan pemerintah.Contoh dari perusahaan negara yang melakukan monopoli adalah PT PLN.

4. Dapat Menikmati Skala Ekonomi

Pada saat sekarang ini perkembangan teknologi berkembang sangat pesat, hampir pada seluruh bidang ekonomi memanfaatkan teknologi.Pemanfaatan teknologi 
tersebut akan membuat proses produksi menjadi lebih efisien, yang hanya bisa dilakukan jika jumlah produksi yang dilakukan besar dan meliputi hampir semua produksi yang dibutuhkan di dalam pasar.Kondisi tersebut menjelaskan bahwa suatu organisasi bisnis atau perorangan hanya akan bisa menikmati skala ekonomi maksimal jika tingkat produksinya besar.

Pada saat organisasi bisnis atau perorangan telah berhasil mencapai kondisi yang dimana biaya produksi mencapai minimal dam jumlah produksi hampir menyamai jumlah permintaan yang ada di pasar.Maka dengan begitu organisasi bisnis atau perorangan tersebut dapat menurunkan harga barangnya jika melakukan produksi dalam jumlah besar.

Hal tersebut akan menyebabkan organisasi bisnis atau perseorangan yang baru atau masih kecil tidak akan bisa untuk bersaing dengan organisasi bisnis atau perseorangan yang sudah mempunyai modal besar dan sudah.

\section{KURVA PERMINTAAN DAN KEKUATAN MONOPOLI}

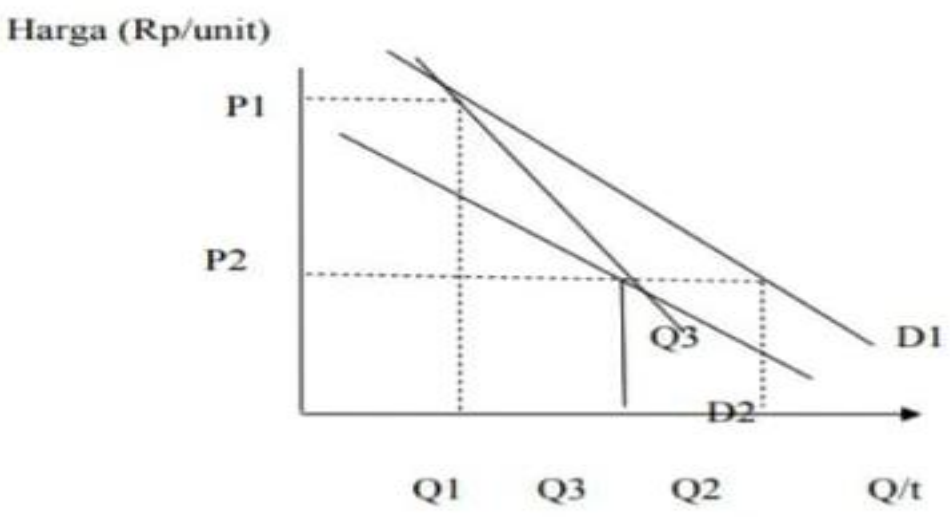

Penjelasan kurva permintaan :

Fenomena pergeseran kurva- kurva permintaan ini dilukiskan dalam gambar diatas. Perusahaan A mula- mula menghasilkan output sebesar Q1 unit dan menjualnya dengan harga P1,kurva permintaan D1 yang berlaku disini, dengan mengkonsumsikan harga-harga yang ditetapkan oleh perusahaan- perusahaan lain tidak berubah. Dengan asumsi tersebut,penurunan harga dari P1 menjadi P2 akan meningkatkan permintaan menjadi $Q 2$. 


\section{E. KURVA PENAWARAN MONOPOLI}

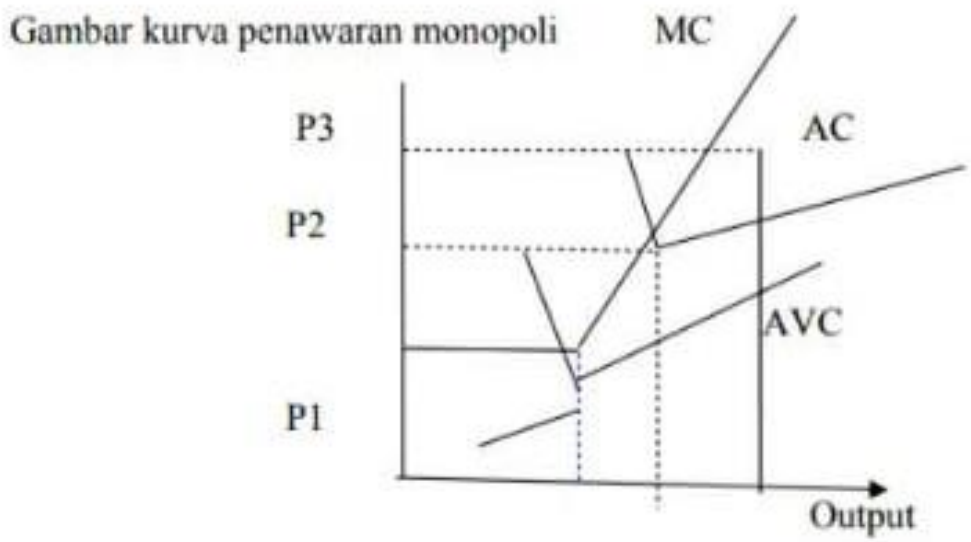

Penjelasan kurva penawaran monopoli :

Gambar diatas menunjukkan jika harga pasar sebesar P1 maka output yang diproduksi perusahaan adalah Q1dan jika harga pasar meningkat menjadi P2 output perusahaan adalah Q3,kurva MC yang dimulai dari P menunjukkan kurva penawaran perusahaan. Berdasarkan kurva penawaran perusahaan, selanjutnya dapat diturunkan kurva penawaran untuk penawaran industri secara keseluruhan. Kurva penawaran industri menunjukkan penjumlahan horisontal dari seluruh kurva penawaran. Penawaran bersaing adalah penjumlahan horisontal dari seluruh kurva biaya marjinal bersaing. Biaya marjinal bersaing adalah penjumlahan horisontal dari seluruh biaya marjinal perusahan - perusahaan yang dimulai dari AVC minimnya.

\section{F. KESEIMBANGAN PERUSAHAAN}

Konsep Pendekatan Keseimbangan Perusahaan

a. Pendekatan keseimbangan

Dalam keadaan seimbang berarti perusahaan mendapatkan normal profit atau minimal profit, sebab pendapatan yang diperoleh perusahaan dapat menutup seluruh biaya perusahaan. Tetapi jika pendapatan melebihi biaya total perusahaan, maka perusahaan dikatakan mendapatkan laba maksimal. Sebaliknya jika pendapatan perusahaan lebih kecil dari biaya perusahaan, maka perusahaan menderita rugi.

Keseimbangan perusahaan dapat diperoleh melalui pendekatan total dan pendekatan marginal. Pendekatan total merupakan pendekatan dimana keseimbangan perusahaan dicari dengan cara membandingkan pendapatan total dengan biaya total.Yang dimaksud dengan pendekatan marjinal adalah dengan pendekatan ini, 
keseimbangan perusahaan dicari dengan cara membandingkan pendapatan marginal dan biaya marginal. Keseimbangan perusahaan, ditampilkan melalui pendekatan total dan marginal.

b. Pendekatan total

Indikator utama dalam pendekatan total adalah pendapatan total dan biaya total. Melalui pendekatan dapat diketahui apakah perusahaan memperoleh laba ataukah rugi. Garis KL, MN dan XY menunjukkan besarnya laba yang diperoleh dari selisih pendapatan total dengan biaya total. Namun, perusahaan mengalami laba maksimum saat MN yaitu saat jarak TR dan TC paling jauh (dengan TR di atas TC). Laba maksimum tersebut dicapai jika perusahaan memproduksi output sebesar OQM.

Memperhatikan posisi laba melalui TR dan TC (pendekatan total) di atas, ternyata pendekatan total ini tidak dapat menunjukkan beberapa hal berikut ini:

- Beberapa harga dan biaya per unit.

- Pada output beberapa terjadi profit maksimal.

- Untuk mendapatkan data tersebut, dapat diperoleh melalui average revenue, marginal revenue, average cost, dan marginal cost (pendekatan marginal).

c. Pendekatan Marginal

Indikator menentukan keseimbangan perusahaan adalah penerimaan rerata dan penerimaan, marginal serta biaya rerata dan biaya marginal. Posisi laba ditampilkan dalam kurva di bawah ini.Kurva Keseimbangan Perusahaan Melalui Pendekatan Marginal

Pada output sebesar OQm, pengusahaan mencapai laba maksimal karena pada saat itu MR=MC. Kurva itu juga menjelaskan harga per unit atau AR = OP dan biaya per unit atau $\mathrm{AC}=\mathrm{OC}$. Besarnya laba ditunjukkan oleh segi empat CPMN yang merupakan selisih antara penerimaan total yaitu OPMQm dengan biaya total yaitu OCNQm.

\section{G. MONOPOLI ALAMIAH}

- Pengertian Monopoli Alamiah dalam Dunia Ekonomi

Sedangkan dalam dunia ekonomi dan bisnis, monopoli alamiah merupakan jenis monopoli yang ada karena tingginya biaya awal atau skala ekonomi yang kuat dalam menjalankan usaha di industri tertentu. Perusahaan dengan monopoli alami 
menjadi satu-satunya penyedia produk atau layanan untuk industri dalam geografis tertentu.

- Monopoli alamiah muncul dalam industri yang membutuhkan bahan baku unik, teknologi, atau faktor serupa untuk beroperasi. Monopoli ini bisa berjalan sepanjang waktu mengikuti kondisi pasar, namun adanya praktik bisnis yang tidak adil dapat menghambat persaingan.

- Beberapa monopoli terkadang memang sengaja dibuat untuk mencari keuntungan dengan kecurangan. Seperti contohnya praktik kolusi, merger, akuisisi, dan pengambil alihan dengan cara yang tidak sportif.Kolusi sendiri bisa melibatkan dua atau lebih pihak untuk bersekongkol agar mendapatkan keuntungan pasar, melalui penetapan harga atau kenaikan harga yang terkoordinasi dengan sangat baik dan terstruktur.

- Dengan demikian, akan ada hambatan bagi perusahaan baru untuk memenuhi kebutuhan pasar sehingga terjadi monopoli alamiah. Hal ini senada dengan yang disebutkan oleh Ari Sudarman berikut ini:

a. Produsen memiliki lebih dari satu sumber daya yang dibutuhkan dan merahasiakannya, atau memegang pengetahuan tertentu tentang teknik produksi yang tidak diketahui oleh orang lain.

b. Produsen yang melakukan monopoli punya hak paten untuk setiap output yang dihasilkan.

c. Produsen mendapatkan perizinan khusus oleh pemerintah. Dalam hal ini, pemerintah menunjuk perusahaan tertentu sebagai produsen sekaligus penyalur tunggal produk atau jasa tertentu. Akan tetapi, perusahaan tersebut berjalan dibawah hukum pemerintah pada aspek tertentu dalam praktik operasinya. Pemerintah juga menetapkan tarif, tujuannya agar mencegah masuknya barang sejenis dari luar negeri.

d. Ukuran pasar terlalu kecil untuk dilayani lebih dari satu perusahaan. Contoh pasar yang hanya dapat dilayani oleh satu perusahaan skala produksi optimum adalah perusahaan transportasi, listrik, dan komunikasi.

e. Produsen menerapkan limit pricing policy, yaitu kebijakan penetapan harga sampai tingkat yang paling rendah. Kebijakan ini digunakan untuk mencegah perusahan baru tidak ikut menembus pasar.

f. Untuk mencari keuntungan, produsen membutuhkan produksi dalam skala besar atau disebut dengan economic scale. Sehingga, perusahaan baru sulit memasuki pasar. 


\section{H. KEBAIKAN DAN KEBURUKAN MONOPOLI}

Kebaikan :

a.mampu mendorong efisiensi dlm produksi

b.tidak memerlukan iklan

c.pembeli dan penjual bebas bertindak

d.harga tdk dikendalikan oleh satu penjualatau oelh satu pembeli

keburukan :

a.pekerja menerima gaji rendah

b.terbatasnya kebebasan memilih

c.tdk ada dana utk penelitian dan pengembangan produk

\section{MONOPOLI DALAM PERSPEKTIF ISLAM}

Pasar merupakan tempat bertemunya antara penjual dan pembeli, sekaligus tempat dimana terciptanya harga pasar itu sendiri. Harga Pasar merupakan harga yang disepakati oleh penjual dan pembeli tanpa adanya campur tangan dari pihak pemerintah ataupun pihak lain. Harga pasar ini juga yang nantinya akan menciptkan keseimbangan pasar itu sendiri, karena adanya pertemuan antara permintaan dengan panawaran.

Dalam perspektif islam, pasar merupakan tempat dimana penentuan harga itu terbentuk, serta terjadi secara sukarela (antaradim minkum), hal ini berdasarkan pada (QS An-Nisa: 29) "Janganlah kamu saling memakan harta sesamamu dengan jalan yang bathil, kecuali dengan jalan perniagaan yang berlaku dengan suka sama suka diantaramu...". Islam telah mengatur sedimikan rupa tentang bagaimana seharusnya mekansime pasar itu berjalan.

Melihat realita yang ada, produk-produk yang berasal dari struktur pasar persaingan tidak sempurna lebih mendominasi pasaran dibandingkan dengan produk dari struktur pasar persaingan sempurna, misalnya saja produk dari Pasar Monopoli yang menjadi kebutuhan dasar bagi kehidupan sehari-hari, air, listrik, bahan bakar kendaraan (bensin), jasa transportasi darat kereta api, dan lainnya. Bila salah satu perusahaan tersebut berhenti beroperasi, dapat dibayangkan, pasti kegiatan sehari-hari pun akan sedikit terhambat. Jika tidak ada air ataupun listrik misalnya, setiap orang pasti akan kewalahan. 
Lalu bagaimana pandangan islam mengenai Pasar Monopoli itu sendiri? Pasalnya, perusahaan itulah yang menguasai pasaran, berperan sebagai penentu harga, karena tidak ada yang menyaingi perusahaan tersebut serta produk atau barang yang dihasilkan pun tidak memiliki barang substitusi.

Pada dasarnya, islam membolehkan siapapun berusaha, sesuai prinsip kebebasan ekonomi, tanpa melihat apakah dia satu-satunya produsen (monopoli) atau ada produsen lain. Dalam islam monopoli dibolehkan, namun mengambil keuntungan diatas keuntungan normal dengan cara menjual barang lebih sedikit (ikhtikar) adalah haram. Hal ini berdasar (Hadits Riwayat Ibnu Majah dan Ahmad) yang mengatakan bahwa "Barangsiapa yang melakukan ikhtikar untuk merusak harga pasar sehingga harga naik secara tajam maka ia berdosa".

Maknanya ialah, Pasar Monopoli dibolehkan dalam islam selama itu tidak melanggar aturan yang ada seperti mengambil keuntungan yang sangat berlebih sehingga menyulitkan konsumen yang ingin menggunakan produk tersebut, dan pada dasarnya segala kegiatan ekonomi dan pasar ini juga harus berdasar pada kemaslahatan bersama agar terciptanya keadilan, serta kemakmuran bagi segala umat. 


\section{BAB III \\ PENUTUP}

\section{A. KESIMPULAN}

Pasar monopoli adalah suatu bentuk pasar di mana hanya terdapat satu perusahaan saja. Dan perusahaan ini menghasilkan barang yang tidak mempunyai barang pengganti yang sangat dekat.

Ciri-ciri antara lain pasar monopoli adalah industri satu perusahaan, tidak mempunyai barang pengganti yang mirip, tidak terdapat kemungkinan untuk masuk ke dalam industri, dapat mempengaruhi penentuan harga, promosi iklan kurang diperlukan.

Faktor-faktor yang menimbulkan monopoli antara lain perusahaan monopoli memiliki suatu sumber daya yang unik dan tidak dimiliki oleh perusahaan lain, perusahaan monopoli pada umumnya dapat menikmati skala ekonomi (economies of scale) hingga ke tingkat produksi yang sangat tinggi, monopoli wujud dan berkembang melalui undang - undang yaitu pemerintah memberi hak monopoli kepada perusahaan tersebut.

\section{B. SARAN}

Dari ciri-ciri dan faktor-faktor tersebut dapat disimpulkan bahwa monopoli cenderung dapat memperburuk distribusi pendapatan dalam masyarakat.

Dengan terselesainya makalah ini semoga bermanfaat bagi teman-teman yang mau mempelajarinya dan dalam pembuatan makalah ini banyak terdapat kesalahan maupun kekurangnya mohon kritik dan saran dari para pembaca. 


\section{DAFTAR PUSTAKA}

http://www.berpendidikan.com/2015/09/pengertian-pasar-monopoli-ciri-ciri-dancontohnya.html?m=1

https://id.m.wikipedia.org/wiki/Pasar_monopoli

http://muhamadkaharudin.blogspot.co.id/2015/11/makalah-pasar-monopoli.html?m=1 https://munikasulistiawati.wordpress.com/2014/08/30/makalah-pasar-monopoli/ http://intanchiechielita.blogspot.co.id/2014/11/makalah-pasar-monopoli.html?m=1 http://www.satujam.com/pasar-monopoli/ http://www.ilmuekonomi.net/2015/10/pengertian-ciri-ciri-karakteristik-contoh-danjenis-jenis-pasar-monopoli.html?m=1 